\title{
Selected aspects of inherited susceptibility to prostate cancer and tumours of different site of origin
}

\author{
Cezary Cybulski \\ Katedra Patologii, Pomorska Akademia Medyczna, Szczecin
}

Key words: prostate cancer, DNA, BRCA1, BRCA2, CHEK2, NBS1

Corresponding author: Cezary Cybulski, Katedra Patologii, Pomorska Akademia Medyczna, ul. Unii Lubelskiej 1, 71-252 Szczecin, phone: +48914253478,fax: +489148700 32,e-mail: sekrpato@sci.pam.szczecin.pl

Submitted: 8 August 2007

Accepted: 4 September 2007

\begin{abstract}
Epidemiologic research conducted over the last two decades has led us to believe that inherited factors play an important role in the aetiology of prostate cancer, but the genes which underlie the inherited susceptibility are elusive. The most compelling associations to date are with genes involved in DNA damage repair, including BRCA2. In Poland we have initiated a programme to identify DNA variants which confer an increased risk of prostate cancer and other cancers. Here we review our recent results. We found that germline mutations in BRCA 1, CHEK2 and NBS 1 confer an increased prostate cancer risk in Polish men. We provide evidence that CHEK2 is a multi-organ cancer susceptibility gene. We show that inherited variation in RNASEL and MSR 1 genes do not contribute to prostate cancer development in Poland.
\end{abstract}

\section{Introduction}

Research conducted over the last two decades has led us to believe that inherited factors play an important role in the aetiology of cancer [1-8]. Prostate cancer is among the leading causes of morbidity and mortality in men. Relatively little is known about the genetic determinants of this disease, but epidemiologic data suggest that dominant susceptibility genes may be responsible for up to $5 \%$ of all of cases [9-10]. Through linkage analysis, numerous chromosomal loci have been identified, but no clear prostate susceptibility gene has emerged. Three candidate susceptibility genes have been positionally cloned - HPC 1, HPC2/ELAC2 and MSR1 - but a clear role for any of these genes in hereditary prostate cancer has not been established [1 1, 12]. There is evidence that rare mutations of genes in the DNA damage signalling pathway and cell cycle control pathway (BRCA2, CHEK2 and NBS1) predispose to prostate cancer, but the contribution of these two genes to prostate cancer aetiology is relatively small [13]. Common variants in the genes in these pathways (CDKN1B, CDKN 1A, ATMATM, XRCC 1, ERCC2) also have been associated with an increased risk of prostate cancer [14-16]. The DNA damage signalling and cell cycle control pathways play a crucial role in the maintenance of the integrity of the genome in response to DNA damage and has been implicated in the pathogenesis of prostate cancer and of cancers at other sites. This paper reviews a range of studies which have been performed in Polish population with the following objectives:

1) to investigate the association between inherited variation in RNASEL, MSR 1, NBS1 and BRCA1 genes and prostate cancer risk in the Polish population;

2) to investigate the role of CHEK2 mutations in inherited susceptibility to prostate cancer and malignancies of other sites in the Polish population. 


\section{Inherited variation in RNASEL, MSR 1, NBS1 and BRCA1 genes and prostate cancer risk in the Polish population}

\subsection{DNA variants in RNASEL and MSRI genes and susceptibility to prostate cancer}

(based on: Cybulski C, Wokołorczyk D, Jakubowska A, Gliniewicz B, Sikorski A, Huzarski T, Debniak T, Narod SA, Lubiński J. DNA variation in MSR 1, RNASEL and E-cadherin genes and prostate cancer in Poland. Urol Int 2007; 79: 44-49)

RNASEL and MSR 1 were identified through linkage studies of prostate cancer families. Two mutations in RNASEL (Metllle and Glu265X) were originally described in familial prostate cancer cases from the USA [17]. Other more common variants in RNASEL (R462Q and D541E) were found to influence the risk of prostate cancer in men [18]. Germline mutations in the MSR 1 gene (six rare missense variants and R293X truncating mutation) were first shown to segregate with hereditary prostate cancer in the USA. Common polymorphisms in MSR 1 have been associated with increased prostate cancer risk [19]. To date, the roles of RNASEL or MSR 1 genes in prostate cancer aetiology have not been investigated in Slavic populations. We investigated if inherited variation in these genes influences prostate cancer risk in Poland.

\section{Materials and methods}

The case group consisted of 737 prostate cancer cases. Of the 737 cases, 506 were from Szczecin and 231 were from other countries (Opole, Bialystok, Olsztyn). Study subjects were unselected for age or family history. Family histories were obtained from each subject. 110 patients had one or more first- or seconddegree relatives with prostate cancer (familial cases). The control group consisted of 511 unselected healthy elderly men aged 50 and above, taken from three family doctors practicing in Szczecin. None of the controls had cancer.

The polymorphisms in MSR 1 and RNASEL were selected after sequencing of the entire coding region of these genes in 52 and 94 Polish men with familial prostate cancer, respectively. Sequencing revealed only two variants in the RNASEL gene (R462Q and D541E) and two variants in the coding sequence of the MSR 1 gene (P275A and R293X). These DNA variants were then genotyped by restriction fragment length polymorphism polymerase chain reaction (RFLP-PCR) using the restriction enzymes Aval (R462Q variant), Mbol (D541E variant), Hpy8I (P275A variant) and Mval (R293X variant).

\section{Results}

The prevalence of the sequence variants in cases and controls is shown is Table 1. The R462Q and D541E

Table 1. Comparison of the frequency of variants in RNASEL and MSR1 genes in 737 patients with prostate cancer and 511 individuals from control group

\begin{tabular}{|c|c|c|c|c|c|c|c|}
\hline \multirow[t]{2}{*}{ Gene } & \multirow[t]{2}{*}{ Variant } & \multirow[t]{2}{*}{ Genotype } & \multicolumn{2}{|c|}{ Number of carriers (frequency) } & \multirow[t]{2}{*}{ OR } & \multirow[t]{2}{*}{$95 \% \mathrm{Cl}$} & \multirow[t]{2}{*}{$\mathrm{p}$} \\
\hline & & & $\begin{array}{c}\text { cases } \\
(n=737) \\
\text { No. }(\%)\end{array}$ & $\begin{array}{c}\text { controls } \\
(n=511) \\
\text { No. (\%) }\end{array}$ & & & \\
\hline \multirow{6}{*}{ RNASEL } & \multirow{3}{*}{$\begin{array}{l}1385 G>A \\
(R 462 Q)\end{array}$} & GG & $245(33.3)$ & $177(34.6)$ & 0.9 & $0.7-1.2$ & 0.6 \\
\hline & & GA & $376(51.0)$ & $252(49.3)$ & 1.1 & $0.9-1.3$ & 0.6 \\
\hline & & AA & $116(15.7)$ & $82(16.1)$ & 1.0 & $0.7-1.3$ & 0.9 \\
\hline & \multirow{3}{*}{$\begin{array}{l}1623 T>G \\
(D 541 E)\end{array}$} & $\mathrm{TT}$ & $111(15.1)$ & $84(16.4)$ & 0.9 & $0.7-1.2$ & 0.5 \\
\hline & & TG & $372(50.5)$ & $259(50.7)$ & 1.0 & $0.8-1.2$ & 1.0 \\
\hline & & GG & $254(34.4)$ & $168(32.9)$ & 1.1 & $0.8-1.4$ & 0.6 \\
\hline \multirow[t]{4}{*}{ MSRT } & \multirow{2}{*}{$\begin{array}{l}945 C>G \\
(P 275 A)\end{array}$} & $\mathrm{CC}$ & $663(90.0)$ & $474(92.8)$ & 0.7 & $0.5-1.1$ & 0.1 \\
\hline & & CG & $74(10.0)$ & $37(7.2)$ & 1.4 & $0.9-2.2$ & 0.1 \\
\hline & \multirow{2}{*}{$\begin{array}{l}999 \mathrm{C}>\mathrm{T} \\
(\mathrm{R} 293 \mathrm{X})\end{array}$} & CC & $725(98.4)$ & $503(98.4)$ & 1.0 & $0.4-2.4$ & 1.0 \\
\hline & & $\mathrm{CT}$ & $12(1.6)$ & $8(1.6)$ & 1.0 & $0.4-2.6$ & 1.0 \\
\hline
\end{tabular}

$\mathrm{Cl}$ - confidence interval; $\mathrm{OR}$ - odds ratio; $\mathrm{p}$ - $\mathrm{p}$-value 
variants of RNASEL were seen in similar frequency in cases and controls. We saw a trend towards a higher frequency of the P275A variant in unselected cases than in controls (10 vs. $7.2 \% ; O R=1.4, p=0.1)$. A truncating MSR 1 R293X mutation was present in $1.6 \%$ of controls, and $1.6 \%$ of unselected cases.

\subsection{Germline 657del5 mutation in the NBSI gene and susceptibility to prostate cancer}

(based on: Cybulski C, Górski B, Debniak T, Gliniewicz B, Mierzejewski M, Masojć B, Jakubowska A, Matyjasik J, Złowocka E, Sikorski A, Narod SA, Lubiński J. NBS1 is a prostate cancer susceptibility gene. Cancer Res 2004; 64: 1215-1219)

Individuals with inherited recessive clinical syndromes, such as Nijmegen breakage syndrome (NBS), which is characterized by spontaneous chromosomal instability, immunodeficiency and a predisposition to cancer, carry a mutation in one of the genes in the DNA damage signalling pathway [20]. The product of the NBS 1 gene is responsible for DNA damage repair [21].

A 5-bp deletion in exon 6 of NBS1 (657del5) is present in the majority of NBS patients from Eastern Europe [22]. This variant is present in approximately $0.6 \%$ of individuals (heterozygous carriers) from the general population in Poland [23, 24]. It has been suggested that heterozygous carriers of the founder mutation of NBS (657del5 allele) might be at increased risk of cancer $[25,26]$, but prostate cancer specifically has not been studied to date.

\section{Materials and methods}

The case group consisted of 340 men diagnosed with prostate cancer at the University Hospital in Szczecin. Family histories of cancer were obtained from each subject. Thirty-five patients had one or more firstor second-degree relatives with prostate cancer (familial cases). We also included a second set of 21 familial cases of prostate cancer from men who were referred for evaluation at the Hereditary Cancer Centre by family doctors or urologists because of familial aggregation of prostate cancers. There were 1500 unaffected control subjects. One thousand control subjects were selected at random from the computerized patient lists of three family practices in Szczecin. A second control group comprised 500 newborns from Szczecin for whom a sample of umbilical cord blood was obtained.

Allele-specific PCR was used to detect the NBS 1 founder mutation in DNA isolated from peripheral blood leukocytes of cases and controls. A separate
DNA sample was sequenced to confirm the presence of the NBS 1 mutation.

For the loss of heterozygosity $(\mathrm{LOH})$ studies, for each of the nine prostate cancers in men with an NBS 1 mutation, a single non-carrier control tumour was selected. The control subject was born within 2 years of the patient and had a tumour of the same Gleason score as the matched patient. DNA was obtained from eight of the nine paraffin-embedded, microdissected tumours from NBS 1 mutation carriers and from all of the nine non-carrier control subjects. For the $\mathrm{LOH}$ analyses, two primer pairs were used, corresponding to the polymorphic microsatellite markers D8S88 and D8S 1811 . PCR was performed using fluorescent primers. PCR products were separated in an ABI PRISM 377 DNA Sequencer (Applied Biosystems). Data collection and analysis were performed using ABI PRISM 377 Collection Software and GenScan Analysis Software Version 3.0 (Applied Biosystems). A signal reduction in one allele of at least $70 \%$ was taken as the threshold of recognition for $\mathrm{LOH}$. The NBS 1 mutant allele is five nucleotides shorter than the wild-type NBS 1 allele. For the $\mathrm{LOH}$ analysis of mutation-positive cases, additional primers were designed specifically to amplify exon 6 of NBS 1 , which contains the deleted sequence. PCR conditions using this primer set were as for allele-specific PCR. This primer set generates two distinct fragments from constitutional DNA from men with an NBS1 deletion.

\section{Results}

The NBS 1 mutation was present in 9 of 340 unselected patients with prostate cancer (2.6\%) compared with only 9 of $1500(0.6 \%)$ control subjects from the general population $(O R=4.5 ; p=0.002)$. The 657 del 5 germline mutation was present in 5 of the 56 (9\%) familial cases $(O R=16 ; p<0.0001)$. We investigated the segregation of the NBS 1 mutant allele with prostate cancer in four families. We were able to establish the mutation status in two affected males from each family; in each family, the NBS 1 mutation was present in both affected members (Figure 1).

To analyze whether the wild-type allele of NBS 1 is lost in prostate cancer, we performed $\mathrm{LOH}$ analysis of microdissected prostate tumours from eight patients who carried the NBS 1 mutation and from nine patients who were found not to carry the NBS 1 mutation. The wild-type NBS 1 allele was lost in seven of eight prostate tumours from carriers of the 657 del 5 allele, but loss of heterozygosity was seen in only one of nine tumours from noncarriers $(p=0.003)$. 
Family 8

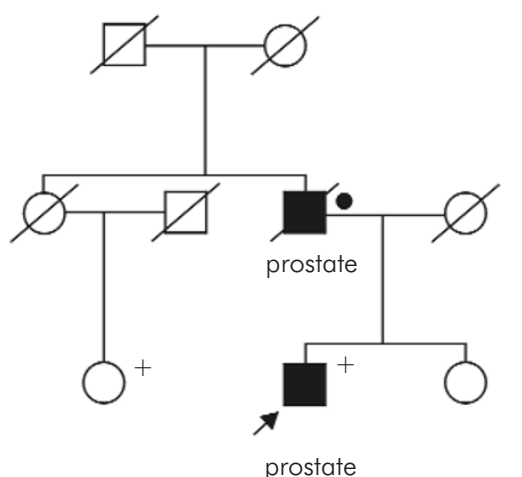

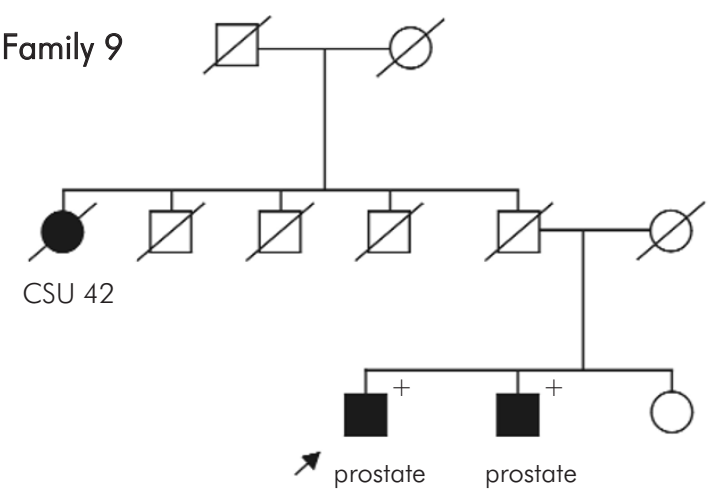

Family 11

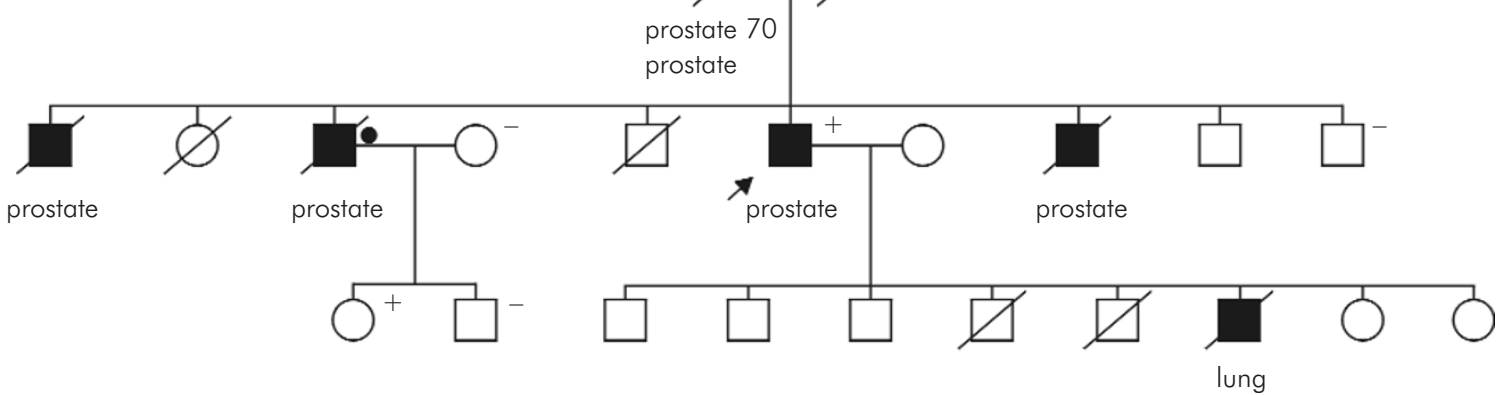

Family 12
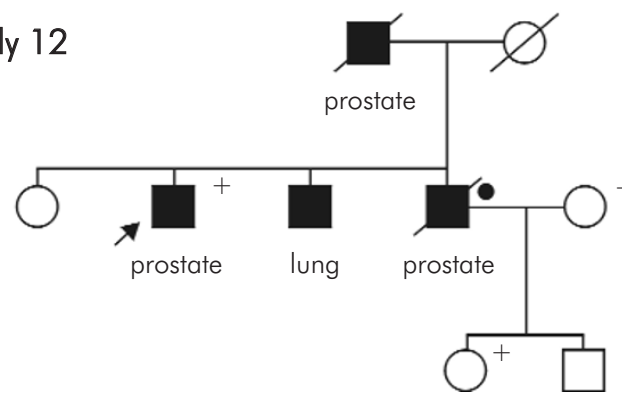

Blackened symbols - individuals with cancer; the type of cancer and age of diagnosis are indicated next to the symbol: CSU - primary cancer site unknown

+ NBS1 mutation carriers

- deceased men with prostate cancer who were likely to be NBS1 mutation carriers

- absence of the mutation

Fig. 1. Pedigrees of NBS1 mutation positive cases with familial prostate cancer

\subsection{Germline mutations in the $B R C A I$ gene and susceptibility to prostate cancer}

(on based: Cybulski $\mathrm{C}$, et al. BRCA1 mutations and prostate cancer in Poland. Eur J Cancer Prev 2007 - in press)

BRCA7 mutations confer high risk of breast and ovarian cancer [27]. Several studies suggested an increased risk of prostate cancer in Ashkenazi Jewish men with a BRCA7 mutation (185delAG or 5382insC) [28-30]. Other studies, in non-Jewish populations, have found little or no evidence of an increased risk for prostate cancer in BRCAl carriers [31-34]. In Poland, there are three common founder alleles in
BRCA1 (C61G, 4153delA and 5382insC), which, in total, account for $90 \%$ of all BRCA] mutations [27]. Here we investigated if Polish men who carry one of these three alleles in BRCAl are at an increased risk of prostate cancer.

\section{Materials and methods}

\section{Patients}

The case group consisted of 1793 unselected prostate cancer cases, collected in 13 centres situated throughout Poland (Szczecin, Bialystok, Olszłyn, Opole, Koszalin, Gdansk, Lublin, Lodz, Warszawa, Wroclaw, 
Table 2. Comparison of the frequency of BRCA1 mutations in 1793 patients with prostate cancer and 4570 controls

\begin{tabular}{lccccc}
\hline Mutation & \multicolumn{2}{c}{ Number of carriers (frequency) } & OR & $95 \% \mathrm{Cl}$ & $\mathrm{p}$ \\
\cline { 2 - 6 } & $\begin{array}{c}\text { cases }(n=1793) \\
\text { No. }(\%)\end{array}$ & $\begin{array}{c}\text { controls }(n=4570) \\
\text { No. }(\%)\end{array}$ & & & \\
\hline BRCA1 & $8(0.45)$ & $22(0.48)$ & 0.9 & $0.4-2.1$ & 1.0 \\
\hline C61G & $3(0.17)$ & $3(0.07)$ & 2.6 & $0.5-12.7$ & 0.5 \\
\hline 4153 delA & $4(0.22)$ & $2(0.04)$ & 5.1 & $0.9-27.9$ & 0.1 \\
\hline 5382insC & $1(0.06)$ & $17(0.37)$ & 0.15 & $0.02-1.1$ & 0.06 \\
\hline $\begin{array}{l}\text { C61G or } \\
4153 \text { delA* }\end{array}$ & $7(0.39)$ & $5(0.11)$ & 3.6 & $1.1-11.3$ & 0.045 \\
\hline
\end{tabular}

$\mathrm{Cl}$ - confidence interval; $\mathrm{OR}$ - odds ratio; $\mathrm{p}$ - $\mathrm{p}$-value

*when 5382ins $C$ is excluded, as unlikely pathogenic for prostate cancer in the Polish population

Poznan, Rzeszow, Sucha Beskidzka). Study subjects were unselected for age or family history. Family histories were obtained from each participant. Two hundred and twenty-nine patients had one or more first- or seconddegree relative with prostate cancer (familial cases).

The control group consisted of a mix of 2000 newborn children from 10 hospitals throughout Poland (Szczecin, Bialystok, Gorzow, Katowice, Wroclaw, Poznan, Opole, Lodz and Rzeszow), 1570 adults selected at random from the patient lists of three family doctors practicing in the Szczecin region and 1000 individuals from Szczecin who submitted blood for paternity testing. In total there were 4570 population controls.

\section{Methods}

The 4153delA and 5382ins C mutations were detected using a multiplex-specific polymerase chain reaction (PCR) assay. The third mutation (C61G) generates a novel restriction enzyme site in exon 5 . This mutation is detected after digesting amplified DNA with Avall. All mutations were confirmed by sequencing.

\section{Results}

A BRCA1 mutation was seen in eight of 1793 $(0.45 \%)$ cases and in 22 of $4570(0.48 \%)$ controls $(\mathrm{OR}=0.9 ; \mathrm{p}=1.0)$ - Table 2. 5382ins $\mathrm{C}$ is the most frequent mutation of the three Polish founder mutations. The 5382insC mutation was detected only in $0.06 \%$ of cases, compared with $0.37 \%$ of controls $(O R=0.15$; $\mathrm{p}=0.06)$. In contrast, $4153 \mathrm{del} A$ was more common in cases than in controls $(0.22$ vs. $0.04 \% ; O R=5.1$; $\mathrm{p}=0.1)$. The C61G mutation was also more frequent in cases than in controls $(0.17$ vs. $0.07 \%$; $O R=2.6$; $p=0.5)$. A statistical test of homogeneity of the $O R$ rejected the null hypothesis that the ORs associated with the three mutations were similar $(p=0.008)$.

A BRCA1 mutation was found in three of 229 (1.3\%) familial prostate cancer cases, compared with five of 4570 controls $(O R=12 ; 95 \%$ confidence interval (CI) 2.9-51; $p=0.0004)$. The 4153 delA mutation was present in one familial case $(O R=10.0 ; p=0.3)$ and $C 61 G$ was responsible for two other prostate cancer families $(O R=13.4 ; p=0.008)$. The family with the 4153delA mutation contained two men with prostate cancer and the families with the C61G mutation contained four and five men with prostate cancer. The C61G segregated with prostate cancer in the two families (Figure 2).

\section{Germline mutations in the CHEK2 gene and their association with predisposition to prostate cancer and tumours of other sites of origin}

\subsection{Identification of point mutations in the CHEK2 gene in the Polish population}

(based on: Cybulski C, Huzarski T, Górski B, Masojć B, Mierzejewski M, Debniak T, Gliniewicz B, Matyjasik J, Złowocka E, Kurzawski G, Sikorski A, Posmyk M, Szwiec M, Czajka R, Narod SA, Lubiński J. A novel founder CHEK2 mutation is associated with increased prostate cancer risk. Cancer Res 2004; 64: 2677-2679)

Germline mutations in the CHEK2 gene have been described in several populations. For example, in the United States, 18 different CHEK2 mutations were found [35]. Two founder variants in the CHEK2 gene (1 100delC and I157T) are present in Finland [36]. In the Ashkenazi Jewish population, a single S428F mutation was detected [37]. In order to identify CHEK2 variants present in the 
Family 1

C61G

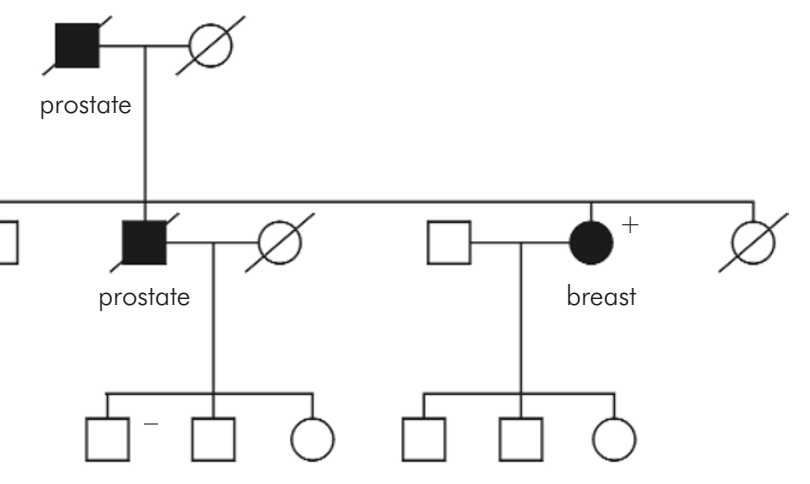

Family 2

C61G

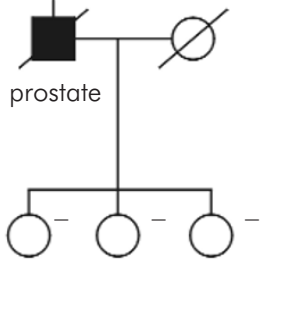

prostate

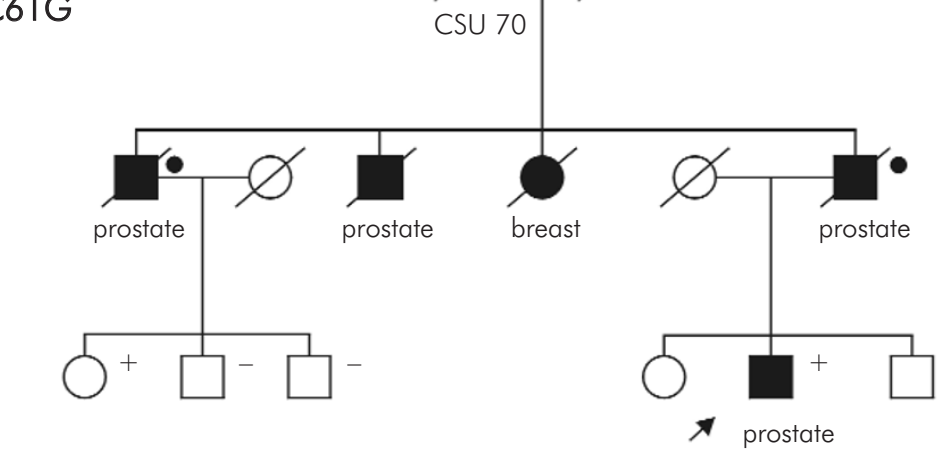

Family 3

4153delA

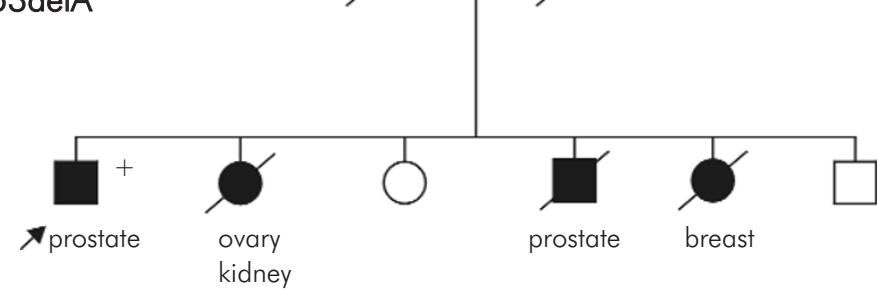

Blackened symbols - individuals with cancer; the type of cancer and age of diagnosis are indicated next to the symbol:

CSU - primary cancer site unknown

+ BRCAl mutation carriers

- deceased men with prostate cancer who were

likely to be BRCA1 mutation carriers

- absence of the mutation

Fig. 2. Pedigrees of $B R C A 7$ mutation positive cases with familial prostate cancer

Polish population, we screened the entire coding CHEK2 sequence in 140 men with prostate cancer.

\section{Materials and methods}

The case group consisted of 140 prostate cancer patients (including 44 familial cases). The entire coding region of the CHEK2 gene was sequenced using primers and conditions described previously [35].

\section{Results}

Three mutations were detected, the 1157T missense variant and two truncating mutations IVS2 + IG>A and 1100delC. 
A.

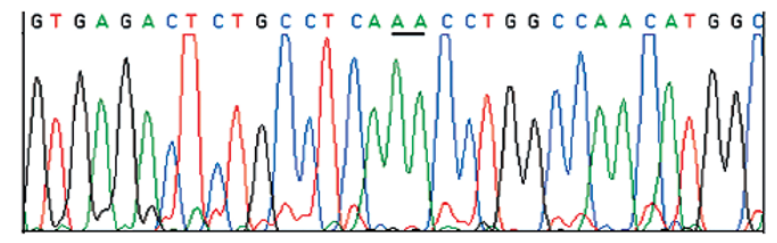

B.

Telomeric breakpoint TGA GAC TCT GCC TCA AA AAA AAA AAA AAT A

Deletion sequence TGA GAC TCT GCC TCA AA CCT GGC CAA CAT G

Centromeric breakpoint CAG GAG TाT GAG ACC AA CCT GGC CAA CAT G

Fig. 3. A 5395 bp deletion of exons 9 and 10 of CHEK2 detected in the Polish population: $A$ - sequencing chromatogram of $P C R$ product containing the deletion; B - location of deletion breakpoints on chromosome 22 in Alu-repeats (shown in bold)

\subsection{Identification of large deletion of exons 9 and 10 of the CHEK2 gene in the Polish population}

(based on: Cybulski C, Wokołorczyk D, Huzarski T, Byrski T, Gronwald J, Górski B, Debniak T, Masoić B, Jakubowska A, Gliniewicz B, Sikorski A, Stawicka M, Godlewski D, Kwias Z, Antczak A, Krajka K, Laver W, Sosnowski M, Sikorska-Radek P, Bar K, Klijer R, Zdrojowy R, Małkiewicz B, Borkowski A, Borkowski T, Szwiec $M$, Narod SA, Lubiński J. A large germline deletion in the CHEK2 kinase gene is associated with an increased risk of prostate cancer. J Med Genet 2006; 43: 863-866)

Recently, a large deletion in CHEK2 was identified in several unrelated patients with breast cancer of Czech or Slovak origin. Haplotype analysis confirmed that the mutation had a single source. The geographical and ethnic extent of this founder allele has not yet been determined [38]. We sought to establish if this deletion is present in the Polish population.

\section{Materials and methods}

Three samples of pooled DNA, each including pooled DNA from about 500 people from Poland, were amplified with primers described previously for the detection of the deletion of exons 9 and 10 [38]. Ninety unpooled DNA samples representing individual controls were also included.

Short extension times (2 $\mathrm{min}$ ) were applied during polymerase chain reaction (PCR) to amplify only a short allele containing the large deletion. A single PCR product of about $1.3 \mathrm{~kb}$ was amplified from all samples with the pooled DNA. The short product was seen in
1 of 90 DNA samples from single patients. The PCR products from all positive cases were sequenced.

\section{Results}

A large deletion of exons 9 and 10 of the CHEK2 gene (del5395) is also a founder mutation in Poland. A single PCR product of about $1.3 \mathrm{~kb}$ was amplified from all samples with the pooled DNA. The short product was seen in 1 of 90 DNA samples from single patients. The PCR products from all positive cases were sequenced. The deletion breakpoints were characterized at a nucleotide level (Figure 3). By our estimate, the length of this deletion is $5395 \mathrm{bp}$, and not $5567 \mathrm{bp}$ as described in the original report [38].

\subsection{CHEK2 mutations and susceptibility to prostate cancer}

(based on: Cybulski C, Wokołorczyk D, Huzarski T, Byrski T, Gronwald J, Górski B, Debniak T, Masoić B, Jakubowska A, Gliniewicz B, Sikorski A, Stawicka M, Godlewski D, Kwias Z, Antczak A, Krajka K, Lauer W, Sosnowski M, Sikorska-Radek P, Bar K, Klijer R, Zdrojowy R, Małkiewicz B, Borkowski A, Borkowski T, Szwiec M, Narod SA, Lubiński J. A large germline deletion in the CHEK2 kinase gene is associated with an increased risk of prostate cancer. J Med Genet 2006; 43: 863-866)

CHEK2 gene mutations have been associated with an increased prostate cancer risk in men from the United States [35] and Finland [39], but the Polish population has not been studied. In this study, we investigated whether CHEK2 plays an important role in the development of prostate cancer in Poland.

\section{Materials and methods}

We studied 1864 prostate cancer cases diagnosed between 1999 and 2005 in 13 centres situated throughout Poland. All the cases were unselected by age and family history. To estimate the frequency of the Polish founder mutations in the general population, three control groups were combined. The first group consisted of 2183 newborn children from 10 cities in Poland (Szczecin, Bialystok, Gorzow, Katowice, Wroclaw, Poznan, Opole, Lodz and Rzeszow) between 2003 and 2006. Samples of cord blood from unselected infants were forwarded to the study centre in Szczecin. The second control group included healthy adult patients (1079 women and 817 men) of three family doctors practicing in the Szczecin region. The third control group consisted of 1417 young adults (705 women and 712 men) from Szczecin who submitted blood for paternity testing.

Large deletion of exons 9 and 10 was genotyped in multiplex PCR reaction. The I157T and IVS2 + 1G>A 
Table 3. Comparison of the frequency of CHEK2 mutations in prostate cancer patients and in the control group

\begin{tabular}{|c|c|c|c|c|c|}
\hline Mutation & Group & $\begin{array}{l}\text { Number of carriers/number of tested } \\
\text { (frequency, \%) }\end{array}$ & OR & $95 \% \mathrm{Cl}$ & $p$ \\
\hline \multirow{3}{*}{ del5395 } & controls & $24 / 5496(0.4)$ & 1.0 & & \\
\hline & unselected cases & 15/1864 (0.8) & 1.9 & $0.97-3.5$ & 0.009 \\
\hline & familial cases & $4 / 249(1.6)$ & 3.7 & $1.3-10.8$ & 0.03 \\
\hline \multirow{3}{*}{1100 delC } & controls & $12 / 5496(0.2)$ & 1.0 & & \\
\hline & unselected cases & $14 / 1864(0.8)$ & 3.5 & $1.6-7.5$ & 0.002 \\
\hline & familial cases & $3 / 249(1.2)$ & 5.6 & $1.6-19.9$ & 0.02 \\
\hline \multirow{3}{*}{ IVS2+1G>A } & controls & $22 / 5496(0.4)$ & 1.0 & & \\
\hline & unselected cases & $15 / 1864(0.8)$ & 2.0 & $1.05-3.9$ & 0.052 \\
\hline & familial cases & $5 / 249(2.0)$ & 5.1 & $1.9-13.6$ & 0.002 \\
\hline \multirow{3}{*}{$\begin{array}{l}\text { Protein } \\
\text { truncating } \\
\text { mutation* }\end{array}$} & controls & $58 / 5496(1.1)$ & 1.0 & & \\
\hline & unselected cases & $44 / 1864(2.4)$ & 2.3 & $1.5-3.4$ & $<0.0001$ \\
\hline & familial cases & $12 / 249(4.8)$ & 4.7 & $2.5-9.0$ & $<0.0001$ \\
\hline \multirow{3}{*}{ 1157T } & controls & $264 / 5496(4.8)$ & 1.0 & & \\
\hline & unselected cases & $142 / 1864(7.6)$ & 1.6 & $1.3-2.0$ & $<0.0001$ \\
\hline & familial cases & $30 / 249$ (12.0) & 2.7 & $1.8-4.1$ & $<0.0001$ \\
\hline \multirow{3}{*}{ CHEK2** } & controls & $321 / 5496(5.8)$ & 1.0 & & \\
\hline & unselected cases & $184 / 1864$ (9.9) & 1.8 & $1.5-2.1$ & $<0.0001$ \\
\hline & familial cases & $42 / 249$ (16.9) & 3.3 & $2.3-4.6$ & $<0.0001$ \\
\hline
\end{tabular}

$\mathrm{Cl}$ - confidence interval; OR - odds ratio; $\mathrm{p}$ - $\mathrm{p}$-value

*one of the three truncating mutations (del5395, IVS2+1G>A, 1100 delC)

**any CHEK2 mutation (del5395, IVS2+1G>A, 1100 delC, 1157T)

variants were analyzed by restriction fragment length polymorphism PCR. 1100delC was analyzed using an allele-specific PCR assay. Positive results were confirmed by sequencing.

\section{Results}

Protein truncating mutations in the CHEK2 gene (del5395, 1100delC, IVS2+1G>A) were more frequent in 1864 men with prostate cancer than in 5496 control individuals (2.4 vs. 1.1\%; OR=2.3; $\mathrm{p}<0.0001)$. The $1157 \mathrm{~T}$ missense mutation was also more common in unselected cases than in controls (7.6 vs. $4.8 \% ; O R=1.6 ; p<0.0001)$. The frequency of CHEK2 mutations was also found to be higher in a series of 249 familial prostate cancer cases than in controls, both for truncating variants (4.8 vs. $1.1 \%$;
$\mathrm{OR}=4,7 ; \mathrm{p}<0.0001)$ and the $1157 \mathrm{~T}$ missense variant (12.0 vs. $4.8 \% ; O R=2.7 ; p<0.0001$ ) (Table 3).

\subsection{CHEK2 mutations and susceptibility to breast cancer}

(based on: Cybulski C, Wokołorczyk D, Huzarski T, Byrski T, Gronwald J, Górski B, Debniak T, Masojć B, Jakubowska A, van de Wetering T, Narod SA, Lubiński J. A deletion in CHEK2 of 5,395 bp predisposes to breast cancer in Poland. Breast Cancer Res Treat 2007; 102:119-122)

A founder allele in CHEK2, 1100 delC, has been reported to be a low-penetrance breast cancer susceptibility allele in several studies, and in many ethnic groups [37, 40-45]. Other CHEK2 variants (IVS2 + 1G>A, I157T, and S428F) have also been suggested to confer increased breast cancer risks [44, 45]. Recently, a large deletion of exons 9 and 10 of 
Table 4. Comparison of CHEK2 mutation frequency in women with breast cancer and in controls

\begin{tabular}{|c|c|c|c|c|c|}
\hline Mutation & Group & $\begin{array}{l}\text { Number of carriers/number of tested } \\
\text { (frequency, \%) }\end{array}$ & OR & $95 \% \mathrm{Cl}$ & $p$ \\
\hline \multirow{3}{*}{ del5395 } & controls & $24 / 5496(0.4)$ & 1.0 & & \\
\hline & unselected cases & 19/1978 (1.8) & 2.2 & $1.2-4.0$ & 0.01 \\
\hline & early onset cases & 28/3229 (0.9) & 2.0 & $1.2-3.4$ & 0.02 \\
\hline \multirow{3}{*}{1100 delC } & controls & $12 / 5496(0.2)$ & 1.0 & & \\
\hline & unselected cases & 10/1978 (0.6) & 2.3 & $1.0-5.4$ & 0.08 \\
\hline & early onset cases & $16 / 3228(0.5)$ & 2.3 & $1.1-4.8$ & 0.04 \\
\hline \multirow{3}{*}{ IVS2+1G>A } & controls & $22 / 5496(0.4)$ & 1.0 & & \\
\hline & unselected cases & $21 / 1978(1.1)$ & 2.7 & $1.5-4.9$ & 0.002 \\
\hline & early onset cases & $31 / 3228$ (1.0) & 2.4 & $1.4-4.2$ & 0.002 \\
\hline \multirow{3}{*}{$\begin{array}{l}\text { Protein } \\
\text { truncating } \\
\text { mutation* }\end{array}$} & controls & $58 / 5496(1.1)$ & 1.0 & & \\
\hline & unselected cases & 49/1978 (2.5) & 2.4 & $1.6-3.5$ & $<0.0001$ \\
\hline & early onset cases & $74 / 3228(2.3)$ & 2.2 & $1.6-3.1$ & $<0.0001$ \\
\hline \multirow{3}{*}{ 1157T } & controls & $264 / 5496(4.8)$ & 1.0 & & \\
\hline & unselected cases & 134/1978 (6.8) & 1.4 & $1.2-1.8$ & 0.001 \\
\hline & early onset cases & $207 / 3228(6.4)$ & 1.4 & $1.1-1.6$ & 0.002 \\
\hline \multirow{3}{*}{ CHEK2** } & controls & $321 / 5496(5.8)$ & 1.0 & & \\
\hline & unselected cases & 180/1978 (9.1) & 1.6 & $1.3-2.0$ & $<0.0001$ \\
\hline & early onset cases & $279 / 3228(8.6)$ & 1.5 & $1.3-1.8$ & $<0.0001$ \\
\hline
\end{tabular}

$\mathrm{Cl}$ - confidence interval; $\mathrm{OR}$ - odds ratio; $\mathrm{p}$ - $\mathrm{p}$-value

*one of the three truncating mutations (del5395, 1100 delC, IVS2 + 1G >A)

**any CHEK2 mutation (del5395, 1100 delC, IVS2+1G>A, 1157T)

CHEK2 was identified in two USA families at high risk of breast cancer [38]. The aim of the study was to establish the relationship between CHEK2 mutations and the risk of breast cancer Poland.

\section{Materials and methods}

This study included prospectively ascertained cases of invasive breast cancer diagnosed throughout Poland from 1996 to 2003. The case group consisted of two groups of women with breast cancer. The first group had 3228 cases diagnosed at age 50 or below. The second group included a sample of 1978 patients, unselected for age. Of these, 752 were under the age of 51 and were also enrolled in the early-onset study described above. All cases were unselected for family history. The control group consisted of 5496 patients. The controls are described in detail in section 2.3.
Genotyping methods are described in detail in section 2.3.

\section{Results}

Protein truncating mutations (del5395, $1100 \mathrm{delC}$, IVS2+1G>A) were observed more frequently in 1978 unselected breast cancer cases compared to controls ( 2.3 vs. $1.1 \% ; p<0.0001$ ). The frequency of missense variant $1157 \mathrm{~T}(p=0.0001)$ was also greater among unselected breast cancer cases than in the control group ( 6.8 vs. $4.8 \% ; p=0.001$ ). The odds ratio for breast cancer associated with truncating mutations $(O R=2.4)$ was greater than that associated with the missense variant 1157T (OR=1.4) - Table 4.

Protein-truncating mutations (del5395, $1100 \mathrm{delC}$, IVS2 $+1 G>A$ ) were detected in $2.2 \%$ of 3228 patients with breast cancer diagnosed before the age of 51 . 
Table 5. Comparison of CHEK2 mutation frequency in patients with colorectal cancer and controls

\begin{tabular}{llllll}
\hline Mutation & Group & $\begin{array}{l}\text { Number of carriers/number of tested } \\
\text { (frequency, \%) }\end{array}$ & OR & $95 \% \mathrm{Cl}$ & $\mathrm{P}$ \\
\hline $\begin{array}{l}\text { Protein } \\
\text { truncating } \\
\text { mutation* }\end{array}$ & controls & $58 / 5496(1.1)$ & 1.0 & \\
\cline { 2 - 6 } & unselected cases & $11 / 1058(1.0)$ & 1.0 & $0.5-1.8$ & 0.9 \\
\cline { 2 - 6 } & familial cases & $2 / 110(1.8)$ & 1.7 & $0.4-7.2$ & 0.44 \\
\hline 1157T & controls & $264 / 5496(4.8)$ & 1.0 & $1.2-2.0$ & 0.002 \\
\cline { 2 - 6 } & unselected cases & $77 / 1085(6.6)$ & 2.2 & $1.2-4.1$ & 0.01 \\
\hline
\end{tabular}

$\mathrm{Cl}$ - confidence interval; $\mathrm{OR}$ - odds ratio; $\mathrm{p}$ - $\mathrm{p}$-value

*one of the three truncating mutations (del5395, 1100delC, IVS2+1G>A)

This frequency was significantly higher $(p<0.0001)$ than in the control group (1.1\%). The missense variant $1157 \mathrm{~T}$ was also significantly more common $(p=0.002)$ among patients with early onset breast cancer $(6.4 \%)$ than in controls (4.8\%). The odds ratio for early onset breast cancer associated with a truncating CHEK2 mutation $(O R=2.2)$ was greater than that associated with the 1157T mutation $(O R=1.4)$ - Table 4.

\subsection{CHEK2 mutations and susceptibility to colorectal cancer}

(based on: Cybulski C, Wokołorczyk D, Kładny J, Kurzawski G, Suchy J, Grabowska E, Gronwald J, Huzarski T, Byrski T, Górski B, D Ecedil Bniak T, Narod SA, Lubiński J. Germline CHEK2 mutations and colorectal cancer risk: different effects of a missense and truncating mutations? Eur J Hum Genet 2007; 15: 237-241)

Germline mutations in CHEK2 have been associated with a range of cancer types, in particular of the breast and the prostate [35-47]. Protein-truncating mutations in CHEK2 have been reported to confer higher risk of cancer of the breast and the prostate than the missense 1157T variant. Recent studies from Finland suggest an increased risk of colon cancer among carriers of missense variant 1157T, but not in carriers of CHEK2 protein truncating mutations [36].

The aim of the study was to evaluate the association between specific CHEK2 alleles and colon cancer.

\section{Materials and methods}

We studied 1085 colorectal cancer cases diagnosed between 1998 and 2005 in three centres in North-Western Poland. Patients were unselected for age and family history. 964 colon cancer cases were diagnosed in Szczecin and 121 cases were diagnosed in Koszalin and Kolobrzeg. One hundred and ten cases had first-degree relatives diagnosed with colon cancer (familial cases). The control group consisted of 5496 patients. The controls are described in detail in section 2.3. Genotyping methods are described in detail in section 2.3.

\section{Results}

The missense mutation 1157T was overrepresented both in unselected cases $(6.6 \%)$ and familial cases $(10 \%)$ with colorectal cancer compared to controls (4.8\%). The OR for unselected colorectal cancer cases with the missense mutation $1157 \mathrm{~T}$ was 1.5 ( $p=0.002)$ - Table 5. The OR for familial cases with the 1157T variant was 2.2 $(p=0.01)$. We saw no association between colorectal cancer risk and CHEK2 truncating alleles.

\subsection{CHEK2 mutations and susceptibility to tumours of other sites of origin}

(based on: Cybulski C, Górski B, Huzarski T, Masoić B, Mierzejewski M, Debniak T, Teodorczyk U, Byrski T, Gronwald J, Matyjasik J, Zlowocka E, Lenner M, Grabowska E, Nej K, Castaneda J, Medrek K, Szymańska A, Szymańska J, Kurzawski G, Suchy J, Oszurek O, Witek A, Narod SA, Lubiński J. CHEK2 is a multiorgan cancer susceptibility gene. Am J Hum Genet 2004; 75: 1131-1135)

CHEK2 mutations originally were found in families with Li-Fraumeni syndrome $[46,47]$. The CHEK2 protein is expressed in a wide range of tissues and participates in the DNA damage response in many cell types; therefore CHEK2 is a good candidate for a multi-site cancer susceptibility gene.

The aim of the study was to assess the range of cancers associated with inactivating mutations in the CHEK2 gene. 


\section{Materials and methods}

To establish the range of cancer types associated with CHEK2 mutations, we genotyped unselected cases of cancer with the most common types of cancer in Poland. In this part the results of 2001 cancer patients are described (excluding cases of the prostate, breast and colon cancers, which are described in detail in previous sections).

The control group consisted of: 2000 newborn children from 10 hospitals throughout Poland (Szczecin, Bialystok, Gorzow, Katowice, Wroclaw, Poznan, Opole, Lodz and Rzeszow); 1000 adult patient lists of three family doctors practicing in the Szczecin region; 1000 adults unselected from family history from Szczecin who submitted blood for paternity testing.

Genotyping methods are described in detail in section 2.3. To confirm the chromosomal location of the observed CHEK2 mutations, we analyzed the polymorphic marker D22S275, which maps to intron 4 of CHEK2. We genotyped: 36 patients with the I157T variant; 24 patients with 1100 delC; 52 patients with IVS2 + 1G>A and 50 individuals from the general population.

\section{Results}

The frequencies of the three CHEK2 variants in cases and controls are presented in Table 6. Because of their different effects on protein synthesis, the two truncating mutations (IVS2 + 1G>A or 1100 delC) were considered separately from the missense mutation (1157T).

CHEK2 truncating alleles were associated with increased risk of breast and prostate cancer (described in the previous sections) and thyroid cancer ( $O R=4.9$; $p=0.0006)$. The missense variant I157T was associated with an increased risk of prostate, breast and colon cancer (described in the previous sections) and in addition with an increased risk of kidney cancer $(O R=2.0$; $p=0.0006)$ and thyroid cancer $(O R=1.9 ; p=0.04)$.

Although any individual finding might be due to chance, our study on the whole suggests that mutations in CHEK2 increase the risk of cancer in many different organs. A total of 52 comparisons were made. Of these, 13 were significant at the $p=0.05$ level $(2.6$ expected by chance) and 5 were significant at the $p=0.01$ level ( 0.5 expected). Furthermore, in all three sites for which a significant association was seen with the truncating mutation, a significant association was also seen with the missense mutation. This would be unlikely to be the case if the observations were due to chance.

To confirm the chromosomal location of the observed CHEK2 mutations we analyzed the polymorphic marker D22S275, which maps to intron 4 of CHEK2. All individuals with the 1100 delC variant or with the 1157T variant carried the $165 \mathrm{bp}$ allele of D22S275, which we estimate has a frequency of 15\% in the Polish population. All individuals with the IVS2 + 1G >A mutation carried the $171 \mathrm{bp}$ allele of the D22S275 marker, which we estimate has a frequency of $8 \%$ in the general population. These observations support the chromosome 22 assignment for the three variant alleles.

\subsection{Clinical characteristics of CHEK2-positive breast cancers in young women from Poland}

(based on: Cybulski C, Górski B, Huzarski T, Byrski T, Gronwald J, Debniak T, Wokolorczyk D, Jakubowska A, Kowalska E, Oszurek O, Narod SA, Lubinski J. CHEK2-positive breast cancers in young Polish women. Clin Cancer Res 2006; 12: 4832-4835)

A founder allele in CHEK2, 1100 delC, has been reported to be a low-penetrance breast cancer susceptibility allele in several studies, and in many ethnic groups. Recent studies reported that patients with the CHEK2 1100 delC variant had a 6-times higher risk of contralateral breast cancer and 3-times higher risk of distant metastasis [42, 48, 49] and more frequently developed ER-positive tumours than non-carriers (91 vs. $69 \% ; p=0.03$ ) [48]. Although the relationship between CHEK2 mutations and breast cancer is well documented, little is known about clinical characteristic of cancers in carriers of CHEK2 mutations.

To investigate the contribution of CHEK2 mutations to early-onset breast cancer in Poland, and to establish the characteristic features of these cancers, we compared clinical and pathological features of CHEK2-positive and CHEK2-negative breast cancers.

\section{Materials and methods}

The case group consisted of 3228 patients with breast cancer diagnosed before age 50, unselected from family history, who tested negative for BRCA1 mutation (4153delA, 5328insC, and C61G). The medical and pathology reports of the cases were reviewed locally by the physician associated with the study and relevant information was forwarded to the study centre in Szczecin. Information was recorded on age at diagnosis, stage, grade and lymph node status, oestrogen-receptor status, multicentricity and bilaterality. The data were collected from at least $70 \%$ of patients. Tumour blocks and/or paraffin-embedded slides were requested from the corresponding pathology centres. A central pathology review of was conducted in Szczecin by two pathologists associated with the study. 
Table 6. Comparison of CHEK2 mutation frequency in patients with selected tumours and in the control group

\begin{tabular}{|c|c|c|c|c|c|}
\hline \multirow[t]{2}{*}{$\begin{array}{l}\text { Location or type } \\
\text { of tumour }\end{array}$} & \multirow[t]{2}{*}{$\begin{array}{l}\text { Number } \\
\text { of tested }\end{array}$} & \multicolumn{4}{|c|}{$\begin{array}{l}\text { Number of mutation carriers (frequency), } \\
\text { results of statistical analysis* }\end{array}$} \\
\hline & & $\mathrm{IVS} 2+1 \mathrm{G}>\mathrm{A}$ & $1100 \mathrm{delC}$ & $\begin{array}{c}1100 \mathrm{delC} \\
\text { or IVS2+1G>A }\end{array}$ & $1157 \mathrm{~T}$ \\
\hline Bladder & 172 & $\begin{array}{c}1(0.6 \%) \\
O R=1.2 \\
p=0.7\end{array}$ & 0 & $\begin{array}{c}1(0.6 \%) \\
O R=0.8 \\
p=0.8\end{array}$ & $\begin{array}{c}12(7.0 \%) \\
O R=1.5 \\
p=0.3\end{array}$ \\
\hline Kidney & 264 & 0 & $\begin{array}{c}2(0.8 \%) \\
O R=2.7 \\
p=0.5\end{array}$ & $\begin{array}{c}2(0.8 \%) \\
O R=1.0 \\
p=0.8\end{array}$ & $\begin{array}{c}26(9.8 \%) \\
O R=2.1 \\
p=0.0006\end{array}$ \\
\hline Larynx & 245 & 0 & 0 & 0 & $\begin{array}{c}10(4.1 \%) \\
O R=0.8 \\
p=0.7\end{array}$ \\
\hline Lung & 272 & 0 & 0 & 0 & $\begin{array}{c}7(2.6 \%) \\
O R=0.5 \\
p=0.1\end{array}$ \\
\hline Melanoma & 129 & $\begin{array}{c}2(1.5 \%) \\
O R=3.3 \\
p=0.3\end{array}$ & $\begin{array}{c}1(0.8 \%) \\
O R=3.1 \\
p=0.8\end{array}$ & $\begin{array}{c}3(2.3 \%) \\
O R=3.2 \\
p=0.1\end{array}$ & $\begin{array}{c}6(4.6 \%) \\
O R=1.0 \\
p=0.9\end{array}$ \\
\hline Ovary & 292 & 0 & 0 & 0 & $\begin{array}{c}14(4.8 \%) \\
O R=1.0 \\
p=0.9\end{array}$ \\
\hline Stomach & 241 & $\begin{array}{l}4(1.7 \%) \\
O R=3.5 \\
p=0.05\end{array}$ & 0 & $\begin{array}{c}4(2.1 \%) \\
O R=2.3 \\
p=0.2\end{array}$ & $\begin{array}{c}13(5.4 \%) \\
O R=1.1 \\
p=0.8\end{array}$ \\
\hline $\mathrm{NHL}$ & 120 & $\begin{array}{c}1(0.8 \%) \\
O R=1.8 \\
p=0.9\end{array}$ & 0 & $\begin{array}{c}1(0.8 \%) \\
O R=1.1 \\
p=0.7\end{array}$ & $\begin{array}{l}11(9.2 \%) \\
O R=2.0 \\
p=0.05\end{array}$ \\
\hline Pancreas & 93 & 0 & 0 & 0 & $\begin{array}{c}6(6.4 \%) \\
O R=1.4 \\
p=0.6\end{array}$ \\
\hline Thyroid & 173 & $\begin{array}{c}5(2.9 \%) \\
O R=6.2 \\
p=0.0003\end{array}$ & $\begin{array}{c}1(0.6 \%) \\
O R=2.3 \\
p=0.9\end{array}$ & $\begin{array}{c}6(3.5 \%) \\
O R=4.9 \\
p=0.0006\end{array}$ & $\begin{array}{c}15(8.7 \%) \\
O R=1.9 \\
p=0.04\end{array}$ \\
\hline Controls & 4000 & 19 (0.475\%) & $10(0.25 \%)$ & $29(0.725 \%)$ & $193(4.825 \%)$ \\
\hline
\end{tabular}

*comparison of CHEK2 mutation frequency in patients with specific tumour type to that of control group

$\mathrm{NHL}$ - non-Hodgkin lymphoma; OR - odds ratio; $\mathrm{p}$ - $\mathrm{p}$-value

\section{Results}

A CHEK2 mutation was identified in 252 of 3,228 women with breast cancer (7.8\%), including $1157 \mathrm{~T}$ (207 times), IVS2 + $1 \mathrm{G}>\mathrm{A}$ (31 times), and $1100 \mathrm{delC}$ (16 times). The mean age of diagnosis in women with a CHEK2 mutation was similar to that of the noncarrier cases. However, the mean age of diagnosis of women with a truncating mutation was 1.8 years lower than women without a CHEK2 mutation (42.5 vs. 44.3 years; $p=0.01$ ).
The characteristics of the breast cancer cases in the 252 women with a CHEK2 mutation are presented in Table 7 and compared with non-carriers. Breast cancers in women with a CHEK2 mutation were more commonly of lobular histology (21.5 vs. $15.8 \%$; $p=0.05)$, of size greater than $2 \mathrm{~cm} \mathrm{(54.8} \mathrm{vs.} 43.5 \%$; $p=0.01)$ or of multi-centric origin (28.7 vs. 19.5\%; $p=0.01$ ) than were cancers from women without a CHEK2 mutation. Intraductal cancers (DCIS) with micro-invasion were also more common in women with a CHEK2 mutation than in non-carriers (1 1.3 vs. 
Table 7. Comparison of breast cancers in patients with CHEK2 mutations to cancers in patients without CHEK2 mutations

\begin{tabular}{|c|c|c|c|c|}
\hline Feature & & $\begin{array}{c}\text { CHEK2-positive cases } \\
(n=252)\end{array}$ & $\begin{array}{c}\text { CHEK2-negative cases } \\
\quad(n=2976)\end{array}$ & $\mathrm{p}$ \\
\hline Age in years (mean) & & 44.2 & 44.3 & 0.7 \\
\hline \multirow[t]{3}{*}{ Age group } & $20-30$ & $3.6 \%(9 / 252)$ & $1.7 \%(52 / 2976)$ & 0.07 \\
\hline & $31-40$ & $15.9 \%(40 / 252)$ & $17.2 \%(512 / 2976)$ & 0.7 \\
\hline & $41-50$ & $80.5 \%(203 / 252)$ & $81 \%(2412 / 2976)$ & 0.9 \\
\hline \multirow[t]{8}{*}{ Histology } & ductal G1-2 grade & $29.3 \%(54 / 186)$ & $26.9 \%(622 / 2315)$ & 0.6 \\
\hline & ductal G3 grade & $10.7 \%(20 / 186)$ & $12.7 \%(294 / 2315)$ & 0.5 \\
\hline & medullary & $2.1 \%(4 / 186)$ & $4.9 \%(113 / 2315)$ & 0.1 \\
\hline & lobular & $21.5 \%(40 / 186)$ & $15.8 \%(366 / 2315)$ & 0.05 \\
\hline & tubulo-lobular & $4.3 \%(8 / 186)$ & $3.6 \%(83 / 2315)$ & 0.8 \\
\hline & $\mathrm{DCIS}$ & $11.3 \%(21 / 186)$ & $7.2 \%(168 / 2315)$ & 0.06 \\
\hline & other & $4.8 \%(9 / 186)$ & $5.1 \%(118 / 2315)$ & 1.0 \\
\hline & missing or unknown & $16.7 \%(31 / 186)$ & $23.8 \%(551 / 2315)$ & 0.03 \\
\hline Pre-operative chemotherapy & & $27.7 \%(66 / 238)$ & $24.5 \%(661 / 2693)$ & 0.3 \\
\hline Oestrogen receptor & positive & $65.1 \%(97 / 149)$ & $63.7 \%(1048 / 1646)$ & 0.8 \\
\hline \multirow[t]{3}{*}{ Tumour size $(\mathrm{cm})$} & $<1 \mathrm{~cm}$ & $5.9 \%(9 / 152)$ & $11.2 \%(193 / 1728)$ & 0.05 \\
\hline & $1-2 \mathrm{~cm}$ & $40.1 \%(61 / 152)$ & $45.3 \%(783 / 1728)$ & 0.2 \\
\hline & $>2 \mathrm{~cm}$ & $53.9 \%(82 / 152)$ & $43.5 \%(752 / 1728)$ & 0.01 \\
\hline Lymph nodes & positive & $45.0 \%(68 / 151)$ & $40.1 \%(722 / 1777)$ & 0.3 \\
\hline Multicentric & & $28.7 \%(41 / 143)$ & $19.5 \%(316 / 1619)$ & 0.01 \\
\hline Bilateral & & $2.3 \%(5 / 215)$ & $3.3 \%(84 / 2531)$ & 0.6 \\
\hline Family history positive* & & $13.8 \%(31 / 224)$ & $8.9 \%(237 / 2652)$ & 0.02 \\
\hline
\end{tabular}

*family history refers to a first-degree relative of a proband affected with breast cancer DCIS - intraductal cancer (ductal carcinoma in situ) with microinvasion; $p$ - p-value

$7.2 \%, p=0.06)$, but this difference was not significant. Carriers and non-carriers were similar with respect to oestrogen receptor status (65.1 vs. $63.7 \% ; p=0.8)$ and lymph node status (45 positive vs. $40.1 \% ; p=0.3$ ). Bilateral tumours were equally common in both subgroups (2.3 vs. $3.3 \% ; p=0.6)$.

The great majority of women with a CHEK2 mutation did not have a strong family of cancer $13.8 \%$ of the women with breast cancer and a CHEK2 mutation were from a family with two or more firstdegree relatives with breast cancer. However, this was more frequent than reported by the non-carriers (8.9\%) and the difference was statistically significant $(O R=1.6$; $p=0.02$ ).

\section{Summary of the results}

1. The entire coding region of the RNASEL gene was sequenced in 94 men with familial prostate cancer and the coding region of the MSRT gene was screened in 52 men with familial prostate cancer. Four DNA variants were detected including R462Q and D541E in the RNASEL gene, and P275A and R293X in the MSR 1 gene. These variants were genotyped in a series of 737 unselected prostate cancer cases and 511 controls, but no significant differences in the allele frequencies were observed.

2. The NBS1 657 del 5 mutation was present in $2.6 \%$ of 340 unselected patients with prostate cancer 
compared with only $0.6 \%$ of 1500 control subjects from the general population $(O R=4.5 ; p=0.002)$. The 657 del 5 germline mutation was present in $9 \%$ of 56 men with familial prostate cancer $(O R=16$; $p<0.0001)$. The 657 del 5 mutation segregated with disease in four families with familial prostate caner. Loss of the wild type NBS 1 allele was observed in seven of eight tumours from men who carried a germline NBS 1 deletion compared with only one of nine NBS 1 mutation-negative prostate tumours $(p=0.003)$.

3. The 5382ins $C$ mutation in the BRCA1 gene was detected only in one of 1793 prostate cancer cases $(0.06 \%)$, whereas it was seen in $0.37 \%$ of 4570 controls $(p=0.06)$. In contrast, the $4153 \mathrm{del} A$ and C61G mutations were found in excess in cases $(0.39 \%)$ compared to controls $(0.11 \%)$. The presence of either of these alleles (C61G or $4153 \mathrm{del}$ A) was associated with an increased risk for prostate cancer $(O R=3.6 ; p=0.045)$, in particular for familial prostate cancer $(O R=12$; $p=0.0004)$. Segregation analysis suggested that the C61G mutation segregated with disease in two families with familial prostate cancer. A statistical test of homogeneity of the odds ratio revealed that the risks associated with the three BRCA1 mutations were different $(p=0.008)$.

4. Three point mutations in the CHEK2 gene (1 100delC, IVS2 + 1G>A, 1157T) were detected by sequencing of DNA isolated from peripheral blood of 140 men with prostate cancer. Large germline deletion of 5395 base pairs in length removing exons 9 and 10 of the CHEK2 gene (del5395) was detected by analysis of samples with pooled DNA, each one including DNAs from approximately 500 individuals from Poland.

5. Protein truncating mutations in the CHEK2 gene (del5395, 1100delC, IVS2+1G>A) were more frequent in 1864 men with prostate cancer than in 5496 control individuals ( 2.4 vs. $1.1 \%$; $O R=2.3$; $\mathrm{p}<0.0001)$. The $1157 \mathrm{~T}$ missense mutation was also more common in unselected cases than in controls (7.6 vs. $4.8 \% ; O R=1.6 ; p<0.0001)$. The frequency of CHEK2 mutations was also found to be higher in a series of 249 familial prostate cancer cases than in controls, both for truncating variants (4.8 vs. 1.1\%; $\mathrm{OR}=4.7 ; \mathrm{p}<0.0001)$ and the $1157 \mathrm{~T}$ missense variant (12.0 vs. $4.8 \% ; O R=2.7 ; p<0.0001)$.

6. Comparison of the frequency of CHEK2 variants in 7540 patients (4454 with breast cancer, 1085 with colorectal cancer, 2001 with other tumours excluding prostate cancer) to that in controls from the general population revealed a positive association of CHEK2 mutations with malignancies of different site of origin. CHEK2 truncating alleles were associated with an increased risk of cancer development in the thyroid $(\mathrm{OR}=4.9 ; \mathrm{p}=0.0006)$ and the breast $(O R=2.4 ; p=0.0001)$. The missense variant I157T was associated with an increased risk of breast cancer $(O R=1.4 ; p=0.001)$, colon cancer $(O R=1.5 ; p=0.002)$, kidney cancer $(O R=2.1$; $p=0.0006)$ and thyroid cancer $(O R=1.9 ; p=0.04)$. The range of cancers associated with $1157 \mathrm{~T}$ missense variant of the CHEK2 gene was greater than that associated with CHEK2 truncating alleles.

7. Evaluation of 3228 unselected breast cancers diagnosed under the age of 51 years revealed that breast cancers in women with a CHEK2 mutation were more commonly of lobular histology (21.5 vs. $15.8 \% ; p=0.05)$, of size greater than $2 \mathrm{~cm}(54.8$ vs. $43.5 \% ; p=0.01)$ or of multi-centric origin $(28.7$ vs. 19.5\%; $p=0.01$ ) than were cancers from women without a CHEK2 mutation. In addition, mutation carriers more frequently had a positive family history of breast cancer than non-carriers (13.8 vs. 8.9\%; $p=0.02)$. Carriers and non-carriers were similar with respect to bilaterality, nodal status and oestrogen receptor status.

\section{General conclusions}

Groups of individuals with an increased risk of prostate cancer in the Polish population can be identified by testing of specific variants in the NBS 7 , BRCA1 and CHEK2 genes. It seems that analysis of the RNASEL and MSR 7 genes is not justified for this purpose. The list of known genetic markers of high risk of prostate cancer (in addition to strong family history of prostate cancer and germline mutations in the BRCA2 gene) may be extended by specific mutations in the NBS1, BRCA1 and CHEK2 genes in men with a positive family history of prostate cancer in at least one $1^{\text {st }}$ or $2^{\text {nd }}$ degree relative (the risk increased about 5-15 fold).

CHEK2 is multi-organ cancer susceptibility gene. It seems justified to consider surveillance of the prostate, breast, thyroid, kidney and colon as an option for carriers of CHEK2 mutations. It appears reasonable to consider magnetic resonance imaging of the breast beginning from the age of $\sim 35$ as an option for mutation carriers, as CHEK2 mutations may predispose to lobular and multifocal cancers in young women. However, the establishment of surveillance protocols for carriers of a CHEK2 mutation requires further studies.

Most carriers of NBS1 and CHEK2 mutations report negative family history of prostate, breast and colorectal cancers. The use of DNA tests is the only 
way to find carriers of these changes conferring increased risk of tumour development. Identification of low penetrance DNA variants may be very important if the simultaneous presence of such alternations and/or combinations with external risk factors in a carrier would add up to a clinically significant high risk of tumour development.

\section{References}

1. Lynch HT, Shaw TG, Lynch JF. Inherited predisposition to cancer: a historical overview. Am J Med Genet C Semin Med Genet 2004; 129: 5-22.

2. Shiao YH. The von Hippel-Lindau gene and protein in tumorigenesis and angiogenesis: a potential target for therapeutic designs. Curr Med Chem 2003; 10: 2461-2470.

3. Guilford P, Hopkins J, Harraway J, McLeod M, McLeod N, Harawira P, Taite H, Scoular R, Miller A, Reeve AE. E-cadherin germline mutations in familial gastric cancer. Nature 1998; 392: 402-405.

4. Reszka E, Wasowicz W, Gromadzinska J. Genetic polymorphism of xenobiotic metabolising enzymes, diet and cancer susceptibility. Br J Nutr 2006; 96: 609-619.

5. Kurzawski G, Suchy J, Kladny J, Grabowska E, Mierzejewski M, Jakubowska A, Debniak T, Cybulski C, Kowalska E, Szych Z, Domagala W, Scott RJ, Lubinski J. The NOD2 3020insC mutation and the risk of colorectal cancer. Cancer Res 2004; 64: 1604-1606.

6. Ylisaukko-Oja SK, Cybulski C, Lehtonen R, Kiuru M, Matyjasik J, Szymańska A, Szymańska-Pasternak J, Dyrskjot L, Butzow R, Orntoft TF, Launonen V, Lubiński J, Aaltonen LA. Germline fumarate hydratase mutations in patients with ovarian mucinous cystadenoma. Eur J Hum Genet 2006; 14: 880-883.

7. Goode EL, Ulrich CM, Potter JD. Polymorphisms in DNA repair genes and associations with cancer risk. Cancer Epidemiol Biomarkers Prev 2002; 11: 1513-1530.

8. Debniak T, Scott RJ, Huzarski T, Byrski T, Masojc B, van de Wetering T, Serrano-Fernandez P, Górski B, Cybulski C, Gronwald J, Debniak B, Maleszka R, Kładny J, Bieniek A, Nagay L, Haus O, Grzybowska E, Wandzel P, Niepsuj S, Narod SA, Lubinski J. XPD common variants and their association with melanoma and breast cancer risk. Breast Cancer Res Treat 2006; 98: 209-215.

9. Steinberg GD, Carter BS, Beaty TH, Childs B, Walsh PC. Family history and the risk of prostate cancer. Prostate 1990; 17: 337-347.

10. Carter BS, Beaty TH, Steinberg GD, Childs B, Walsh PC. Mendelian inheritance of familial prostate cancer. Proc Natl Acad Sci USA 1992; 89: 3367-3371

11. Orr-Urtreger A, Bar-Shira A, Bercovich D, Matarasso N, Rozovsky U, Rosner S, Soloviov S, Rennert G, Kadouri L, Hubert A, Rennert H, Matzkin H. RNASEL mutation screening and association study in Ashkenazi and non-Ashkenazi prostate cancer patients. Cancer Epidemiol Biomarkers Prev 2006; 15: 474-479.

12. Sun J, Hsu FC, Turner AR, Zheng SL, Chang BL, Liu W, Isaacs $W B, X \cup J$. Meta-analysis of association of rare mutations and common sequence variants in the MSR 1 gene and prostate cancer risk. Prostate 2006; 66: 728-737.

13. Dong JT. Prevalent mutations in prostate cancer. J Cell Biochem 2006; 97: 433-447.

14. Kibel AS, Suarez BK, Belani J, Oh J, Webster R, Brophy-Ebbers M, Guo C, Catalona WJ, Picus J, Goodfellow PJ. CDKN1A and CDKNIB polymorphisms and risk of advanced prostate carcinoma. Cancer Res 2003; 63: 2033-2036.

15. Angèle $S$, Falconer $A$, Edwards $S M$, Dörk T, Bremer M, Moullan $N$, Chapot B, Muir K, Houlston R, Norman AR, Bullock S, Hope Q,
Meitz J, Dearnaley D, Dowe A, Southgate C, Ardern-Jones A, Easton DF, Eeles RA, Hall J. ATM polymorphisms as risk factors for prostate cancer development. Br J Cancer 2004; 91: 783-787.

16. Rybicki BA, Conti DV, Moreira A, Cicek M, Casey G, Witte JS. DNA repair gene XRCC1 and XPD polymorphisms and risk of prostate cancer. Cancer Epidemiol Biomarkers Prev 2004; 13: 23-29.

17. Carpten J, Nupponen N, Isaacs S, Sood R, Robbins C, Xu J, Faruque M, Moses T, Ewing C, Gillanders E, Hu P, Bujnovszky P, Makalowska I, Baffoe-Bonnie A, Faith D, Smith J, Stephan D, Wiley K, Brownstein M, Gildea D, Kelly B, Jenkins R, Hostetter G, Matikainen M, Schleutker J, Klinger K, Connors T, Xiang Y, Wang Z, De Marzo A, Papadopoulos N, Kallioniemi OP, Burk R, Meyers D, Grönberg H, Meltzer P, Silverman R, Bailey-Wilson J, Walsh P, Isaacs W, Trent J. Germline mutations in the ribonuclease $\mathrm{L}$ gene in families showing linkage with $\mathrm{HPCl}$. Nat Genet 2002; 30: 181-184.

18. Casey G, Neville PJ, Plummer SJ, Xiang Y, Krumroy LM, Klein EA, Catalona WJ, Nupponen N, Carpten JD, Trent JM, Silverman $\mathrm{RH}$, Witte JS. RNASEL Arg462GIn variant is implicated in up to $13 \%$ of prostate cancer cases. Nat Genet 2002; 32: 581-583.

19. Xu J, Zheng SL, Komiya A, Mychaleckyi JC, Isaacs SD, Hu JJ, Sterling D, Lange EM, Hawkins GA, Turner A, Ewing CM, Faith DA, Johnson JR, Suzuki H, Bujnovszky P, Wiley KE, DeMarzo AM, Bova GS, Chang B, Hall MC, McCullough DL, Partin AW, Kassabian VS, Carpten JD, Bailey-Wilson JE, Trent JM, Ohar J, Bleecker ER, Walsh PC, Isaacs WB, Meyers DA. Germline mutations and sequence variants of the macrophage scavenger receptor 1 gene are associated with prostate cancer risk. Nat Genet 2002; 32: 321-325.

20. Futaki M, Liu JM. Chromosome breakage syndromes and the BRCA1 genome surveillance complex. Trends Mol Med 2001; 7: 560-565.

21. Varon R, Vissinga C, Platzer M, Cerosaletti KM, Chrzanowska KH, Saar K, Beckmann G, Seemanová E, Cooper PR, Nowak NJ, Stumm M, Weemaes CM, Gatti RA, Wilson RK, Digweed M, Rosenthal A, Sperling K, Concannon P, Reis A. Nibrin, a novel DNA double-strand break repair protein, is mutated in Nijmegen breakage syndrome. Cell 1998; 93: 467-476.

22. Voelkel-Johnson C, Voeks DJ, Greenberg NM, Barrios R, Maggouta F, Kurtz DT, Schwartz DA, Keller GM, Papenbrock T, Clawson GA, Norris JS. Genomic instability-based transgenic models of prostate cancer. Carcinogenesis 2000; 21: 1623-1627.

23. Fan Z, Chakravarty P, Alfieri A, Pandita TK, Vikram B, Guha C. Adenovirus-mediated antisense ATM gene transfer sensitizes prostate cancer cells to radiation. Cancer Gene Ther 2000; 7: 1307-1314

24. Steffen J, Varon R, Mosor M, Maneva G, Maurer M, Stumm M, Nowakowska D, Rubach M, Kosakowska E, Ruka W, Nowecki Z, Rutkowski P, Demkow T, Sadowska M, Bidziński M, Gawrychowski K, Sperling K. Increased cancer risk of heterozygotes with NBS 1 germline mutations in Poland. Int J Cancer 2004; 111 : 67-71.

25. Steffen J, Nowakowska D, Niwińska A, Czapczak D, Kluska A, Piatkowska M, Wiśniewska A, Paszko Z. Germline mutations 657 del5 of the NBS1 gene contribute significantly to the incidence of breast cancer in Central Poland. Int J Cancer 2006; 119: 472-475.

26. Gorski B, Debniak T, Masojc B, Mierzejewski M, Medrek K, Cybulski C, Jakubowska A, Kurzawski G, Chosia M, Scott R, Lubinski J. Germline 657del5 mutation in the NBS1 gene in breast cancer patients. Int J Cancer 2003; 106: 379-381.

27. Górski B, Byrski T, Huzarski T, Jakubowska A, Menkiszak J, Gronwald J, Pluzańska A, Bebenek M, Fischer-Maliszewska L, Grzybowska E, Narod SA, Lubiński J. Founder mutations in the BRCA1 gene in Polish families with breast-ovarian cancer. Am J Hum Genet 2000; 66: 1963-1968. 
28. Struewing JP, Hartge $P$, Wacholder $S$, Baker SM, Berlin $M$, McAdams M, Timmerman MM, Brody LC, Tucker MA. The risk of cancer associated with specific mutations of BRCA1 and BRCA2 among Ashkenazi Jews. N Engl J Med 1997; 336: 1401-1408.

29. Warner E, Foulkes W, Goodwin P, Meschino W, Blondal J, Paterson C, Ozcelik H, Goss P, Allingham-Hawkins D, Hame N, Di Prospero L, Contiga V, Serruya C, Klein M, Moslehi R, Honeyford J, Liede A, Glendon G, Brunet JS, Narod S. Prevalence and penetrance of BRCA1 and BRCA2 gene mutations in unselected Ashkenazi Jewish women with breast cancer. J Natl Cancer Inst 1999; 91: 1241-1247.

30. Giusti RM, Rutter JL, Duray PH, Freedman LS, Konichezky M, Fisher-Fischbein J, et al. A twofold increase in BRCA mutation related prostate cancer among Ashkenazi Israelis is not associated with distinctive histopathology. J Med Genet 2003; 40: 787-792.

31. Thompson D, Easton DF; Breast Cancer Linkage Consortium. Cancer incidence in BRCA1 mutation carriers. J Natl Cancer Inst 2002; 94: 1358-1365.

32. Sinclair CS, Berry R, Schaid D, Thibodeau SN, Couch FJ. BRCAT and BRCA2 have limited a role in familial prostate cancer Cancer Res 2000; 60: 1371-1375.

33. Ikonen T, Matikainen MP, Syriäkoski K, Mononen N, Koivisto PA, Rökman A, Seppälä EH, Kallioniemi OP, Tammela TL, Schleutker J. BRCA1 and BRCA2 mutations have no major role in predisposition to prostate cancer in Finland. J Med Genet 2003; 40: e98.

34. Zuhlke KA, Madeoy JJ, Beebe-Dimmer J, White KA, Griffin A, Lange EM, Gruber SB, Ostrander EA, Cooney KA. Truncating BRCA1 mutations are uncommon in a cohort of hereditary prostate cancer families with evidence of linkage to $17 q$ markers. Clin Cancer Res 2004; 10: 5975-5980.

35. Dong X, Wang L, Taniguchi K, Wang X, Cunningham JM, McDonnell SK, Qian C, Marks AF, Slager SL, Peterson BJ, Smith DI, Cheville JC, Blute ML, Jacobsen SJ, Schaid DJ, Tindall DJ, Thibodeau SN, Liu W. Mutations in CHEK2 associated with prostate cancer risk. Am J Hum Genet 2003; 72: 270-280.

36. Kilpivaara $O$, Alhopuro P, Vahteristo P, Aaltonen LA, Nevanlinna $\mathrm{H}$. CHEK2 I157T associates with familial and sporadic colorectal cancer. J Med Genet 2006; 43: e34.

37. Shaag A, Walsh T, Renbaum P, Kirchhoff T, Nafa K, Shiovitz S, Mandell JB, Welcsh P, Lee MK, Ellis N, Offit K, Levy-Lahad E, King MC. Functional and genomic approaches reveal an ancient CHEK2 allele associated with breast cancer in the Ashkenazi Jewish population. Hum Mol Genet 2005; 14: 555-563.

38. Walsh T, Casadei S, Coats KH, Swisher E, Stray SM, Higgins J, Roach KC, Mandell J, Lee MK, Ciernikova S, Foretova L, Soucek P, King MC. Spectrum of mutations in BRCA1, BRCA2, CHEK2, and TP53 in families at high risk of breast cancer. JAMA 2006; $295 ; 1379-1388$

39. Seppälä EH, Ikonen T, Mononen N, Autio V, Rökman A Matikainen MP, Tammela TL, Schleutker J. CHEK2 variants associate with hereditary prostate cancer. Br J Cancer 2003; 89: 1966-1970

40. CHEK2 Breast Cancer Consortium: Low-penetrance susceptibility to breast cancer due to $\mathrm{CHEK} 2 * 1100$ delC in noncarriers of BRCA1 or BRCA2 mutations. Nat Genet 2002; 31: 55-59.

41. Oldenburg RA, Kroeze-Jansema K, Kraan J, Morreau H, Klijn JG, Hoogerbrugge N, Ligtenberg MJ, van Asperen CJ, Vasen HF, Meijers C, Meijers-Heiiboer H, de Bock TH, Cornelisse CJ, Devilee P. The CHEK2*1 100delC variant acts as a breast cancer risk modifier in non-BRCA1/BRCA2 multiple-case families. Cancer Res 2003; 63: 8153-8157.

42. Vahteristo P, Bartkova J, Eerola H, Syrjakoski K, Ojala S, Kilpivaara $\mathrm{O}$, et al. A CHEK2 genetic variant contributing to a substantial fraction of familial breast cancer. Am J Hum Genet 2002; 71: 432-438.
43. CHEK2 Breast Cancer Case-Control Consortium: CHEK2*1100delC and susceptibility to breast cancer: a collaborative analysis involving 10,860 breast cancer cases and 9,065 controls from 10 studies. Am J Hum Genet 2004; 74: 1175-1182.

44. Kilpivaara O, Vahteristo P, Falck J, Syriäkoski K, Eerola H, Easton D, Bartkova J, Lukas J, Heikkilä P, Aittomäki K, Holli K, Blomqvist C, Kallioniemi OP, Bartek J, Nevanlinna H. CHEK2 variant I157T may be associated with increased breast cancer risk. Int J Cancer 2004; 111 : 543-547.

45. Bogdanova N, Enssen-Dubrowinskaja N, Feshchenko S, Lazjuk GI, Rogov YI, Dammann O, Bremer M, Karstens JH, Sohn C, Dörk T. Association of two mutations in the CHEK2 gene with breast cancer. Int J Cancer 2005; 1 16: 263-266.

46. Bell DW, Varley JM, Szydlo TE, Kang DH, Wahrer DC, Shannon KE, Lubratovich M, Verselis SJ, Isselbacher KJ, Fraumeni JF, Birch JM, Li FP, Garber JE, Haber DA. Heterozygous germ line hCHK2 mutations in Li-Fraumeni syndrome. Science 1999; 286: 2528-2531.

47. Vahteristo P, Tamminen A, Karvinen P, Eerola H, Eklund C, Aaltonen LA, Blomqvist C, Aittomäki K, Nevanlinna H. p53, $\mathrm{CHK} 2$, and $\mathrm{CHK} 1$ genes in finnish families with Li-Fraumeni syndrome: further evidence of CHK2 in inherited cancer predisposition. Cancer Res 2001; 61: 5718-5722.

48. de Bock GH, Schutte M, Krol-Warmerdam EM, Seynaeve C, Blom J, Brekelmans CT, Meijers-Heiiboer H, van Asperen CJ, Cornelisse CJ, Devilee P, Tollenaar RA, Kliin JG. Tumour characteristics and prognosis of breast cancer patients carrying the germline CHEK2*1 100delC variant. J Med Genet 2004; 41: 731-735.

49. Broeks A, de Witte L, Nooijen A, Huseinovic A, Klijn JG, van Leeuwen FE, Russell NS, van'† Veer LJ. Excess risk for contralateral breast cancer in CHEK2*1100delC germline mutation carriers. Breast Cancer Res Treat 2004; 83: 91 -93. 